IRA-International Journal of Education \& Multidisciplinary Studies

ISSN 2455-2526; Vol.06, Issue 02 (2017)

Pg. no. 163-169

Institute of Research Advances

http://research-advances.org/index.php/IJEMS

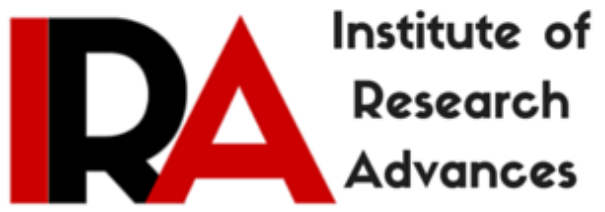

\title{
Action Research in Schools and Utility for Teachers
}

\section{Chetna Arora}

Department of Education,

Lady Irwin College, Delhi University, New Delhi, India.

Type of Review: Peer Reviewed.

DOI: http://dx.doi.org/10.21013/jems.v6.n2.p3

\section{How to cite this paper:}

Arora, C. (2017). Action Research in Schools and Utility for Teachers. IRA International

Journal of Education and Multidisciplinary Studies (ISSN 2455-2526), 6(2), 163-169. doi:http://dx.doi.org/10.21013/jems.v6.n2.p3

(C) Institute of Research Advances

\section{(c) ) BY-NO}

This work is licensed under a Creative Commons Attribution-Non Commercial 4.0 International License subject to proper citation to the publication source of the work.

Disclaimer: The scholarly papers as reviewed and published by the Institute of Research Advances (IRA) are the views and opinions of their respective authors and are not the views or opinions of the IRA. The IRA disclaims of any harm or loss caused due to the published content to any party. 


\section{ABSTRACT}

Action Research is a self - reflective inquiry by participants, undertaken in order to improve their own educational practices in classroom situations. Action research is most helpful when it is self-critical and starts from recognition of a problem or statement, understanding, collecting data and then self-evaluating and then finally improving teaching practices. Action research has multiplier affect not only for teachers wherein they improve their teaching practices but also positive impact on students' engagement and renewed interest in classroom and studies.

Keywords: Action Research, Teacher, Schools, Self-reflection

\section{Introduction}

Action research according to Kurt Lewin is a "a comparative research on the conditions and effects of various forms of social action and research leading to social action"; this type of research uses " a spiral step," each of which is "composed of a circle of planning, action and fact - finding about the result of the action'".

Carr and Kemmins (1986) describe action research as:

- The improvement of practice

- The improvement of the understanding of practice; and

- The improvement of the situation in which the practice takes place.

Action Research is a self - reflective inquiry by participants, undertaken in order to improve their own educational practices in classroom situations.

\section{Following are the characteristic features of Action Research:}

- Action research improves education by changing it and learning from the consequences of change

- Action research is participatory; it is research through which a person works to improves his/her practices

- It is a self-reflective cycle (cyclic process) which involves planning, acting (implementing plans), observing systematically, reflecting and then re-planning, further implementation, observing and reflecting.

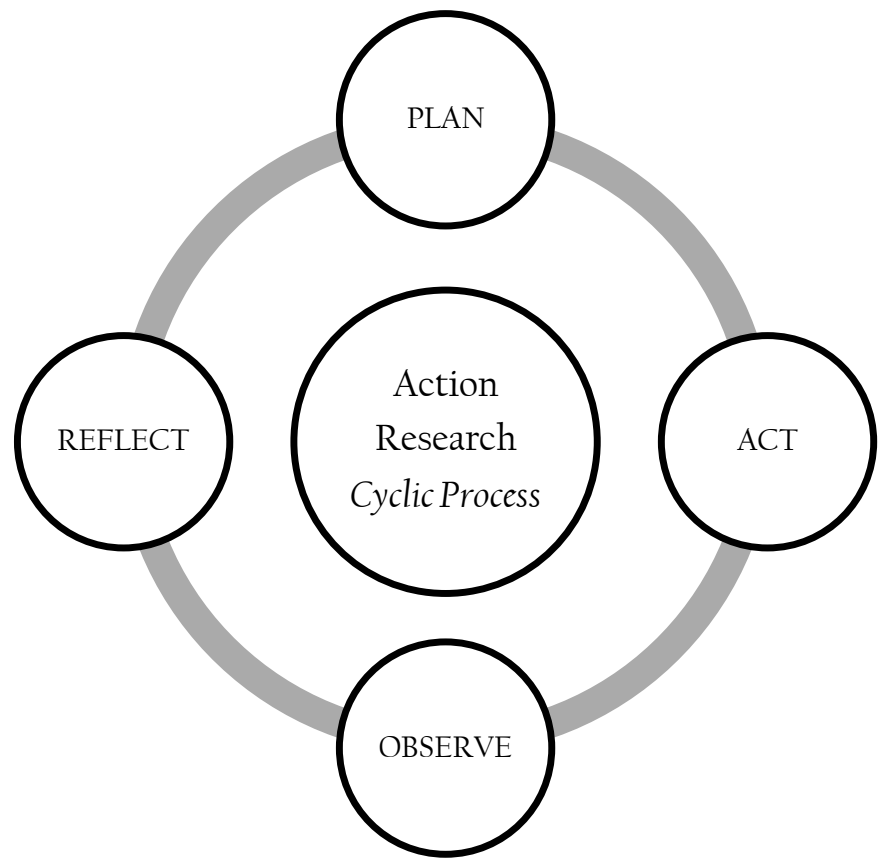


- Action research is collaborative in approach as it involves those responsible for action in improving it

- It involves self - critical analysis of the situations (classrooms schools, systems) in which they work as the research process involves the planning, action, observation and the reflection

- It is a systematic learning process as the individual plans, acts, observes and reflects.

- Action research involves people theorizing about their practices. The person in inquisitive about its own actions.

- It helps to test their own practices, ideas and assumptions in 21 st century

- Action research allows to build records of improvements as we record our progress and reflections

- Action research helps us to give justification of our educational work to others as it involves critical reflection.

Thus in action researches the teacher or the practitioners can take up and solve a number of problems in more systematic and scientific manner in a class room. For example -

- A Science teacher observes that student's performance is better in practical exam than in theory.

- A Maths teacher finds that the performance of class in term one is not so good as compared to term two in maths.

- An English teacher observe that students in her class students' scores more in writing skills than in speaking skills.

In both the above situations the teacher can conduct an action research in order to improve his / her own practices

Thus, an action research is a cyclic process which involves: identification of problem, planning an intervention, implementing the intervention, evaluating the outcome and critically reflecting upon the practice. It is the participatory practitioner research by the user, for the user for its professional development.

Action research is a continuous and reflective process which involves the following steps

1. Identification of problem

2. Plan the action

3. Data collection

4. Data analysis

5. Using and Sharing the findings

6. Review /Reflect

1. Identification of Problem

For action research, problem emerges out of perceived dissatisfaction with the existing situation and also with the need for bringing out improvement in the situation.

2. Plan the Action

This step involves planning and development of a suitable intervention programme, its implementation and examining its effectiveness. The duration of the intervention, modality of its implementation with respect to remediation measures etc. need to be carefully planned.

3. Data Collection

It includes the sample of the study, tools developed/identified for the study and method of the study. 
4. Data Analysis

It indicates the statistical technique that will be used for analysis of data.

5. Using and Sharing the findings

After the completion of the study, it is beneficial to share the results and findings with the colleagues, administrators and other functionaries. The sharing can be done through presentation in seminar, conference and also publication in journals, newspapers etc.

6. Review /Reflect

It helps one to reflect upon her own study as to how the study has helped in improving one's own educational practices in classroom situations.

Tools and techniques of data collection include procedures and techniques to be adopted for data collection. It refers to the nature of the sample to be chosen for study and selection and development of data gathering devices. They are classified as follows

1. Inquiry form

- Questionnaire

- Schedule

- Check list

- Rating scale

- Attitude scale

2. Observation

3. Interview

4. Sociometry

5. Psychological tests and Inventories

- Achievement test

- Aptitude test

- Inventory

6. Field Notes

7. Video and Audio Recordings

The goal of action research is to understand some element of your classroom by collecting data. Data (plural) are any form of information, observations, or facts that are collected or recorded. Action research involves collecting data and making conclusions based on that data.

Five C's by Borgia and Schuler

Borgia and Schuler describe components of Action Research as ' C's. These are presented in this picture 


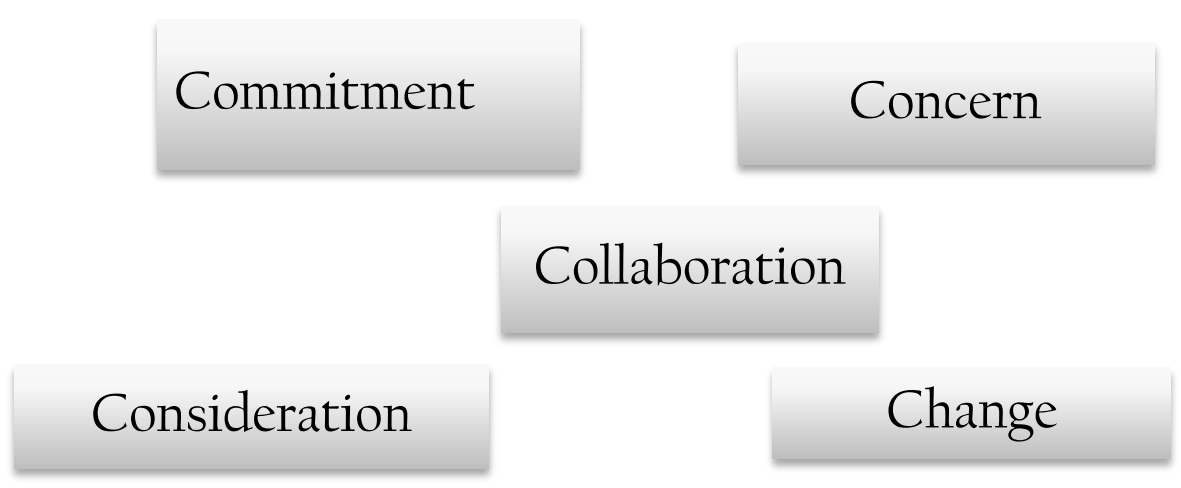

(Borgia and Schuler, Action Research in Early Childhood Education; University of Illinois, Urban Champaign,1996)

- Commitment: Time commitment should be carefully considered by participants of action research since it takes them time to get acquainted with other participants, think about change, try new approach, collect data, and interpret results.

- Collaboration: In an action research, all participants are at par with each other's in all respects, such as, giving ideas, suggestions, feelings, and actions which lead to success.

- Concern: In the research process, participants build up a group of intimates who trust each other and value the project.

- Consideration: A reflective practice is a mindful review of a professional research like action research. It demands concentration and careful consideration as one seeks patterns and relationships that will create meaning within the investigation.

- Change: For humans, especially teachers, change is a continuous process and it is a significant element in remaining academically and naturally alive.

\section{Merits of Action Research}

Pal. H.R. (2004) in his book Educational Research presented the following Merits of Action Research:

- Action research has immediate utility because it gives timely solutions to the problem.

- Action Research is a process which, in every phase, has close contact with the reality.

- In Action Research the researchers utilize sample, tools and statistical techniques according to their researching ability and available resources.

- Teachers, supervisors and administrators use action research to improve their activities and decisions. (Goods, 1959)

\section{Types of Action Research}

Creswell (2005) defines two types of Action Research as follows:

1. Practical Action Research

2. Participatory Action Research

Practical action research is used in situations in which teacher researchers "seek to enhance the practices of education through the systematic study of a local problem." It usually involves a small case study research project, directed at a specific problem or issue and is undertaken by individual teachers or team 
within a particular educational setting. For example, effectiveness of using an out pass for moving out of the classroom so as to maintain discipline.

Participatory action research is usually implemented in large scale to improve "the quality of people's organization, communities and family lives", namely, it has a "Social and Community Orientation" and focuses on Research that "contributes to emancipation or change in our change in our society, for example - effectiveness of new teaching strategy in improving teaching learning experience.

\begin{tabular}{|l|l|}
\hline Practical Action Research & Participatory Action Research \\
\hline Studying local practices & $\begin{array}{l}\text { Studying social issues that constrain individual } \\
\text { lives }\end{array}$ \\
\hline Involving individual or team - base inquiry & Emphasizing " equal" collaboration \\
\hline $\begin{array}{l}\text { Focussing on teacher development and student } \\
\text { learning }\end{array}$ & Focusing on "Life - enhancing change" \\
\hline $\begin{array}{l}\text { Implementing a plan of action developing the } \\
\text { teacher into a researcher }\end{array}$ & Resulting in the emancipated researchers \\
\hline
\end{tabular}

- Classroom Action Research

It is a teacher-initiated, school-based research used to improve the practitioner's practice by doing or changing own practices to improve teacher learning experiences. It begins with a question or questions about classroom experiences, issues, or challenges

It is a reflective process which helps teachers to explore and examine aspects of teaching and learning and to take action to change and improve. Teachers can conduct, practice-oriented research to improve their classroom practice by collecting data about their daily activities, problems, and outcomes for the purpose of improving themselves as teachers and their students as learners

\section{Utility for School Teachers}

1. The reflective practices are multi layered because the teacher engages in self-study and inquiry to examine his or her own practice, then that teacher's report is shared with a wider audience for further exploration through collaborative reflection. When shared with colleagues in their schools, the outcomes of their action research appear to have had wider impact on teaching and learning that goes beyond their individual classrooms.

2. The self-study research process provides more insight into the benefits of this approach to teacher educators who teach research courses and who work with in-service teachers to better their teaching practice. Thus, helps in improving the teaching practice by better understanding of one's own teaching.

3. This investigation suggests that critical reflection around issues of knowledge sharing and transfer in teacher education programs can improve educational practice.

4. It also highlighted that we can improve the teaching learning classroom experiences both for the students and teachers by making explicit connections between teaching and learning so that when teachers engage in their own action research they are more apt to recognize these connections.

5. It positively impacts student outcomes in classrooms by following ways

a) Fostering students' active participation in the learning process.

b) Increasing students' responsibility, and fostering independence. 
c) Promoting opportunities for students to develop enjoyment for reading.

d) Collaborating through teacher-to-teacher common planning.

e) Identifying and addressing students' individual needs.

f) Considering students' multiple intelligences when teaching and developing activities

Thus it helps in creating a conducive and congenial classroom environment for learning.

Taking the time to reflect critically on the things we are doing in our classrooms is perhaps the most effective thing we can do to ensure that what we are doing is having the desired outcomes, and is changing our practice in the ways we want it to." Wenmoth, 2007

\section{References}

1. Borgia, E. T., \& Schuler, D. (1996). Action Research in Early Childhood Education. ERIC Digest.

2. Creswell, J. W. (2002). Educational research: Planning, conducting, and evaluating quantitative (pp. 146-166). Upper Saddle River, NJ: Prentice Hall.

3. Hewitt, R., \& Little, M. (2005). Leading action research in schools. Daytona Beach: University of Central Florida, Department of Education.

4. Hien, T. T. T. (2016). Why is action research suitable for education?. VNU Journal of Science: Foreign Studies, 25(2).

5. Hong, C. E., \& Lawrence, S. (2011). Action research in teacher education: Classroom inquiry, reflection, and data-driven decision making. Journal of Inquiry and Action in Education, 4(2), 1.

6. Kemmis, S., \& Carr, W. (1986). Becoming critical. Education, knowledge and action research, Lewes: Falmer.

7. Kumar, Kuldeep, (1997). Training Models on Action Research Technology. NCERT, New Delhi.

8. Lewin, K. (1946). Action research and minority problems. Journal of social issues, 2(4), 34-46.

9. Pal, H.R, (2004). Educational Research. Madhya Pardesh Hindi Granth Academy, RNT Marg, Banganga Bhopal.

10. Shumsky, A. (1958). The action research way of learning. Bureau of Publications, Teachers College, Columbia University.

11. Wichadee, S. Learning from Peers: The Important Step of Self-Development for EFL Teachers. 